JOURNAL

OF TOURISM

AND ECONOMIC
Journal of Tourism and Economic Vol.4, No.1, 2021, Page 73-84

ISSN: 2622-4631 (print), ISSN: 2622-495X (online)

Email: jurnalapi@gmail.com

Website: http://jurnal.stieparapi.ac.id/index.php/JTEC

DOI: https://doi.org/10.36594/jtec.v4i1.112

\title{
ANALISA PENGARUH SOP ( STANDARD OPERATING PROCEDURE) TERHADAP KINERJA WAITER DAN WAITRESS DI IN BLOOM RESTORAN HOTEL AYAARTTA MALIOBORO YOGYAKARTA, INDONESIA
}

\author{
Slamet Supriyanto \\ Sekolah Tinggi Pariwisata AMPTA Yogyakarta, Indonesia, \\ slamet700@gmail.com \\ Lutfi Hendriyati \\ Akademi Pariwisata Yogyakarta \\ lutfihendriyati.slamet@gmail.com
}

\begin{abstract}
Standard operating procedures or commonly called SOPs are important things that every company must have and must be a guide in carrying out work activities by all waiters and waiters at In Bloom Restaurant Hotel Ayaartta Malioboro Yogyakarta. This research uses a quantitative approach method, using data from questionnaires and uncovering problems in the form of numerical scores, which are then processed and tested by statistical analysis techniques in an effort to reveal the performance and effectiveness of SOP implementation in carrying out tasks at Bloom's Restaurant.
\end{abstract}

Keywords: SOP, Performance, Waiter \& Waitress, Restaurant 


\begin{abstract}
ABSTRAK
Prosedur Standar Operasi atau Standard Operating Procedures biasa juga disebut SOP merupakan hal penting yang harus dimiliki setiap perusahaan dan harus menjadi pegangan dalam melakukan kegiatan bekerjaan oleh semua waiter dan waitress di In Bloom Restaurant Hotel Ayaartta Malioboro Yogyakarta. Penelitian menggunakan metode pendekatan kuantitatif, dengan menggunakan data dari angket dan mengungkap masalah dalam bentuk skor angka data kuantitatif yang selanjutnya diolah dan diuji dengan tehnik analisis statistika dalam upaya mengungkap kinerja dan efektifitas pelaksanaan SOP dalam pelaksanaan tugas di In Bloom Restaurant.
\end{abstract}

Kata Kunci: SOP, Kinerja, Waiter \& Waitress, Restoran 


\section{PENDAHULUAN}

Standard operating procedure atau biasa disingkat SOP merupakan sesuatu yang yang sangat penting dalam sitem operasi disebuah hotel, khususnya di In Bloom Restoran Ayaartta Hotel Malioboro, mengingat hal tersebut masih menjadi sebuah permasalahan yang tidak disadari tetapi berlangsung terus menerus, sehingga dapat mengganggu standarisasi pekerjaan yang dilakukan oleh setiap individu, yaitu pihak waiter dan waitress yang langsung melaksanakan tugas kesehariannya.

Perputaran karyawan secara interen ( Rolling ) maupun masuknya karyawan baru, baik yang sudah berpengalaman maupun yang belum berpengalaman berpengaruh terhadap pelaksanaan SOP dan hubungannya dengan standarisasi kerja akibat dari pelaksanaan SOP di In Bloom Restoran. Perpindahan interen ( Rolling ) dan masuknya karyawan baru biasanya hanya dibekali breafing singkat tentang SOP, serta mengenai peraturan perusahaan. SOP mendapatkan porsi yang sangat kecil dan minim dari pihak personalia, pihak personalia menyerahkan sepenuhnya kepada departemen yang bersangkutan, dikhawatirkan standar pekerjaan akan terganggu, tamu merasa bingung dan tidak terpuaskan oleh standar pelayanan yang diberikan oleh staff dilapangan.

Permasalahan SOP tersebut akan semakin komplek manakala dijumpai karyawan yang nol pengalaman, sehingga akan mengakibatkan kebinggungan dari karyawan baru tersebut, ditambah masuknya karyawan baru yang sudah memiliki pengalaman dan pengalaman tersebut dari hotel atau restoran yang berbeda, sehingga mereka akan membawa dan menerapkan sistem kerja dari perusahaan lama mereka, akibatnya SOP tidak standar lagi bagi setiap karyawan, sehingga kinerja setiap waiter dan waitress menjadi rancu serta terdapat perbedaan yang sangat tajam dari setiap individunya.
Akibat ketidaksamaan standar dan kinerja tersebut, berakibat akan terjadi variasi pelayanan yang banyak dan berbeda, sehingga akan membingungkan bagi banyak staff serta kualitas pelayanan terhadap tamu akan berbeda pula, permasalahan ini tidak akan terasa manakala tamu mendapatkan pelayanan sesuai yang mereka inginkan, walaupun berbeda standarnya, tetapi akan berbeda ceritanya apabila tamu merasa tidak terpuaskan dan mengeluh dengan apa yang dia dapatkan, sehingga penyelesaianya akan lebih rumit, karena tidak adanya kesamaan dalam menyelesaikan masalah tersebut.

Permasalahan SOP dan penerapan kinerja yang sesuai harus diselesaikan dengan baik apabila tetap ingin bertahan dalam bisnis tersebut, apa lagi menengok kompetitor semakin banyak dengan munculnya hotel baru, mereka menawarkan hal yang lebih kreatif dan mengikuti perkembangan jaman, apalagi infrastruktur, perlengkapan dan kelengkapan yang masih baru, didukung dengan staff yang lebih muda dan enerjik serta harga yang lebih kompetitif, tidak kalah pentingnya adalah, mereka mampu membuat SOP yang begitu kreatif dan dinamis menyesuaikan dinamika perkembangan jaman serta tuntutan konsumen yang dibarengi dengan tingkat kinerja yang cenderung seragam dan baik.

Bagi hotel tergolong baru berdiri dan baru memiliki SOP, tetapi tidak pernah diberikan kepada karyawanya secara baik, berkala dan berkelanjutan serta tingkat kinerja yang cenderung menurun kemungkinan besar akan ditinggalkan oleh konsumen. SOP yang tidak pernah disosialisasikan kepada semua staff, apa lagi memperbaharui SOP sesuai dengan perkembangan jaman, akan berakibat turunnya kinerja karyawan dan berakibat buruk terhadap perusahaan tersebut, pelan tapi pasti.

Melihat permasalahan tersebut, dapat dipastikan bahwa SOP dan kinerja adalah sesuatu yang mendasar yang harus 
ada didalam sebuah restoran, tidak hanya sekedar ada, tetapi harus diberikan kepada semua karyawan baik yang baru maupun karyawan yang sudah lama, SOP harus dijalankan dengan penuh kesadaran serta disiplin, dimonitor, diawasi dan diberikan pelatihan secara terus menerus, diadakan pembaharuan sesuai dengan keadaan perusahaan dan perkembangan jaman untuk meningkatkan kinerja yang baik.

Diakui atau tidak, disadari atau tidak, SOP selain dasar dari semua pelaksanaan tugas karyawan, SOP pula dapat menjadikan perusahaan tersebut berbeda, berkualitas, elegan, unik dalam melancarkan semua aktifitas kerja dalam perusahaan tersebut serta dapat meningkatkan kinerja karyawan. Sehingga akan banyak mempengaruhi nama baik serta kelangsungan hidup perusahaan tersebut.

Dengan melihat permasalahan tersebut diatas, maka penulis mengambil penelitian mengenai " Pengaruh SOP (Standard Operating procedure) Terhadap Kinerja Waiter dan Waitress Di In Bloom Restoran Ayaartta Hotel. Dengan pemikiran diatas, diharapkan pelaksanaan SOP yang baik dan benar akan memberikan pengaruh positif terhadap peningkatan kinerja waiter dan waiterss dengan harapan berdampak bagi lancarnya operasional di Inbloom Restoran yang dapat diterima oleh semua kalangan waiter, waitress serta pihak terkait didalamnya.

\section{TINJAUAN LITERATUR}

\section{Pengertian SOP:}

\section{Menurut M.Budiharjo ( 2014:7 ) dalam bukunya Panduan Praktis} Menyusun SOP ( Standard Operating Procedure ), adalah suatu perangkat lunak pengatur, yang mengatur tahapan suatu proses kerja atau prosedur kerja tertentu. Oleh karenya prosedur kerja yang dimaksud bersifat tetap, rutin, dan tidak berubah-ubah, prosedur kerja tersebut dibakukan menjadi dokumen tertulis.
Menurut Annie Sailendra (2015) memberikan Batasan bahwa, "SOP dapat diartikan sebagai panduan proses kerja yang harus dilaksanakan setiap elemen perusahaan maupun instansi"

"Aturan tertulis dan standar operasi kerja dan aturan tidak tertulis adalah memiliki bobot ( penting ) dan sebagai norma dalam mengontrol kegiatan kerja disebuah organisasi. Lebih khususnya bagaimana karyawan menjaga atau mengatur penampilan dan aturan kerja di organisasinya, dan menset / membuat uraian-uraian peraturan siapa yang bertanggung jawab terhadap peraturan tersebut',

Pengertian SOP menurut Menurut Purnamasari (2015) SOP adalah prosedur kerja yang dibuat secara detail dan terperinci bagi semua karyawan untuk melaksanakan pekerjaan dengan sebaikbaiknya sesuai dengan misi,visi, dan tujuan suatu lembaga, intansi, atau lembaga)

Pengertian SOP menurut Arini T. Seomohadiwidjojo (2014) menjelaskan bahwa; Standard Operating Procedure (SOP), atau disebut juga sebagai "Prosedur", adalah dokumen yang lebih jelas dan rinci untuk menjabarkan metode yang digunalan untuk mengimplemantasikan dan melaksanakan kebijakan dalam suatu organisasi seperti yang ditetapkan dalam pedoman. SOP adalah 1 set perintah kerja atau langkahlangkah yg harus diikuti untuk menjalankan suatu pekerjaan dgn berpedoman pada tujuan yg harus dicapai.

Dari pengertian diatas maka dapat diartikan bahwa SOP adalah penting dalam sebuah perusahaan. Perumusan SOP menjadirelevan karena sebagai tolok ukur dalam meniai efektivitas dan efisiensi kerja karyawan dalam melaksanakan program kerjanya. Secara konseptual prosedur dapat diartikan sebagai langkahlangkah menjalankan sejumlah instruksi secara logis untuk menuju pada suatu proses yang dikehendaki, atau sering kita sebut tujuan pencapain ( goal ). Proses 
tersebut berupa sistem kerja dalam bentuk aktivitas, aliran data dan aliran kerja. Sedangkan prosedur operasonal standar adalah sejumlah instruksi logis yang harus dilakukan berupa aktivitas, aliran data dan aliran kerja.

Dilihat dari fungsinya, SOP berfungsi membentuk sistem kerja dan aliran kerja yang teratur, sistematis dan dapat dipertanggung jawabkan, menggambarkan bagaimana tujuan pekerjaan dilaksanakan sesuai dengan kebijakan dan peraturan yang berlaku, menjelaskan bagaimana proses ( kegiatan ) pekerjaan berlangsung, sebagai sarana tata urutan dari pelaksanaan dan pengadministrasian pekerjaan harian sebagaimana metode yang telah ditetepkan, menjamin konsistensi dan proses kerja yang sistematik dan menetapkan hubungan timbal balik antara satuan kerja.

\section{Tahapan Penyusunan SOP}

Menurut M.Budiharjo (2014) Tahapan penting dalam penyusunan SOP adalah melakukan analisis sistem dan prosedur kerja, analisis tugas dan melakukan analisis prosedur kerja.

\section{Tahapan Penyusunan SOP}

\section{1) Analisis Sistem dan Prosedur Kerja}

Analisis sistem dan prosedur kerja adalah kegiatan mengidentifikasikan fungsi-fungsi utama dalam suatu pekerjaan, dan langkah-langkah yang diperlukan dalam melaksanakan fungsi sistem dan prosedur kerja. Sistem adalah suatu unsur atau unit yang saling berhubungan dan saling mempengaruhi sedemikian rupa, sehingga muncul dalam bentuk keseluruhan, bekerja, berfungsi atau bergerak secara harmonis yang ditopang oleh sejumlah prosedur yang diperlukan, sedang prosedur merupakan urutan kerja atau kegiatan yang terencana untuk menangani pekerjaan yang berulang dengan cara seragam dan terpadu

\section{2) Analisis Tugas}

Analisis tugas merupakan proses menejemen yang merupakan penelaahan yang mendalam dan teratur terhadap suatu pekerjaan. Analisis tugas diharapkan dapat memberikan keterangan mengenai pekerjaan, sifat pekerjaan, syarat pejabat, dan tanggung jawab pejabat. Sedikitnya ada 5 aspek yang berkaitan langsung dengan analisis tugas yaitu: a). Analisa Tugas Merupakan penghimpunan informasi dengan sistematis dan penetapan seluruh unsur yang tercakup dalam pelaksanaan tugas khusus. b).Deskripsi Tugas Merupakan garis besar data informasi yang dihimpun dari analisa tugas, disajikan dalam bentuk terorganisasi yang mengidentifikasikan dan menjelaskan isi tugas atau jabatan tertentu. Diskripsi tugas harus disusun berdasarkan fungsi atau posisi, bukan individu.c).Spesifikasi Tugas, Berisi catatan-catatan terperinci mengenai kemampuan pekerja untuk tugas spesifik.d).Penilaian Tugas Berupa prosedur penggolongan dan penentuan kualitas tugas untuk menetapkan serangkaian nilai moneter untuk tugas spesifik dalam hubungannya dengan tugas lain e). Pengukuran Kerja dan Penentuan Standar Tugas Merupakan prosedur penetapan waktu yang diperlukan untuk menyelasaikan setiap tugas dan menetapkan ukuran yang dipergunakan untuk menghitung tingkat pelaksanaan pekerjaan.

\section{Kriteria Dokumen SOP}

Sebagai suatu manual, dokumen SOP perlu memiliki beberapa kriteria yang pada dasarnya dimaksudkan agar dokumen SOP benar-benar unggul dan dapat diandalkan, dan sedapat mungkin memiliki manfaat yang maksimal bagi organisasi ataupun perusahaan, kriteria dokumen SOP menurut M.Budiharjo(2014) adalah Penyusunan kalimat dengan bahasa sederhana dan mudah dipahami, Mudah diaplikasikan, Mudah dikontro,. Mudah 
diaudit , Mudah diubah, disesuaikan perkembangan jaman dan Mengikat

\section{Pengertian Waiter/ss}

Menurut Marsum W.A dan Siti Fauziah (2016), pramusaji dapat diartikan sebagai : 1. Seseorang yang melayani makan minum tamu di dalam sebuah restoran. 2. Seseorang yang menyajikan makanan dan minuman di dalam sebuah restoran dan bar.

Pramusaji atau waiter/ss adalah karyawan restoran, bar dan sejenisnya, yang mempunyai tugas dan tanggung jawab melayani kebutuhan makanan dan minuman secara profesional bagi pera pelanggan. Dengan komunikasi yang baik dengan para pelanggan, seorang pramusaji dapat mendeteksi keinginan dan kebutuhan para pelanggan dan segera mewujudkannya. Oleh karena itu, pramusaji restoran harus dapat melayani kebutuhan makan dan minum para tamu dengan baik dan memuaskan.

Dari Pengertian waiter dan waiterss diatas dapat disimpulkan tugas waiter yaitu Menyambut tamu dengan ramah dan bersahabat, Mempersilahkan tamu duduk, Memberikan daftar menu, Mengambil pesanan makanan dan minuman, Menyajikan makanan dan minuman, Menerima pembayaran tamu, Mengucapakan terima kasih pada saat tamu selesai mekan dan minum, dan mengharapkan untuk datang kembali

\section{Pengertian restoran}

Restoran adalah suatu tempat atau bangunan yang diorganisasi secara komersial yang menyelenggarakan pelayanan dengan baik kepada semua tamu baik berupa makanan maupun minuman (ED, Durachim. Hamzah, 2017).

Dalam Sujatno (2011) dikatakan bahwa restoran berasal dari bahasa Perancis yaitu restoratives yang berati obat yang menyegarkan dengan harapan dapat memberikan penyegaran bagi orang banyak. Kata tersebut menimbulkan imajinasi dan melahirkan banyak ide guna menarik pasar, yang pada akhirnya menjadi bisnis yang dinamis dengan variasi dan keunikan masing-masing. Restoran merupakan salah satu bidang usaha yang mendukung perkembangan industri pariwisata. Restoran sekarang ini sudah tidak hanya menjual makanan saja, melainkan pelayanan juga suasana yang dapat diberikan kepada para pelanggannya sedangkan Prihandini dan Mayasari (2019) mengemukakan bahwa Restoran merupakan industri dimana didalamnya memiliki beberapa outlet dan bagian yang memberikan pelayanan kepada tamu yang datang dengan baik dan sopan, Restoran juga disediakan untuk mereka yang sedang bepergian jauh/dekat, Restoran juga memiliki fyngsi seperti Pelayanan kamar, buffet service (Pelayanan makan prasmanan) dan acara hotel lainnya yang memerlukan jasa dari departemen.

Dari definisi diatas maka dapat penulis simpulkan adalah restoran merupakan bagian kegiatan yang berhubungan dengan makanan dan minuman, yang dijalankan secara profesional dan dijalankan secara profesional demi keuntungan perusahaan dan kepuasan tamu.

Beberapa jenis Restoran seperti Table D'hote Restoran Yaitu restoran yang khusus menjual susunan menu yang lengkap dari menu makanan pembuka sampai makanan penutup biasanya penjualannya tersedia di hotel hotel, Coffee shop atau Brasserie adalah Tempat makan yang biasanya berhubungan dengan hotel, suatu tempat dimana tamu bisa mendapatkan makan pagi, makan siang dan makan malam secara cepat dengan harga relatif murah, kadang penyajiannya secara prasmanan, Cafetaria atau cafe adalah suatu restoran kecil yang mengutamakan makanan ringan seperti sandwich, kopi maupun teh dengan suasana yang lebih santai, Canteen biasanya terdapat di perkanotran, sekolah sekolah maupun pabrik, Dining room Terdapat dihotel kecil, merupakan tempat yang tidak ekonomis dari pada tempat 
makan biasa, dining room biasanya disediakan untuk para tamu yang tinggal dihotel itu, namun terbuka juga untuk tamu dari luar, Inn Tavern yaitu restoran denganharga terjangkau biasanya dikelola oleh perorangan ditepi kota, Pizzeria adalah restoran yang khusus menyediakan atau menjual pizza, spaghetti serta makanan khas Italia contohnya Pizza HUT. Restoran Khusus, Restoran ini menyediakan makanan ,suasana, dekorasi, begitu juga dengan cara penyajiannya yang khas dari negara tertentu contohnya Restoran Padang, Restoran Cina, Restoran jepang, Family Restaurant adalah restoran menyediakan makanan dan minuman untuk tamu-tamu keluarga atau rombongan dengan berbagai menu yang ditawarkan dan disajikan secara cepat.

\section{Pengertian kinerja}

Menurut Mangkunegara (2011)

Kinerja karyawan adalah hasil kerja secara kualitas dan kuantitas yang di capai oleh seorang pegawai dalam melaksanakan tugasnya sesuai dengan tanggung jawab yang di berikan kepadanya. Menurut Tjutju Yuniarsih dan Suwanto (2011) Kinerja merupakan prestasi nyata yang di tampilkan seseorang setelah yang bersangkutan menjalankan tugas dan perannya dalam organisasi..

Pada awalnya performa dalam bahasa Ingris diartikan kedalam bahasa Indonesia dengan beragam arti seperti unjuk kerja, kinerja, hasil karya. Tetapi umumnya yang sering dipakai adalah kinerja yang berarti hasil kerja yang dapat dicapai seseorang atau sekelompok orang dalam suatu organisasi, sesuai kewenangan dan tanggung jawab masing-masing, dalam rangka mencapai tujuan organisasi secara legal, tidak melanggar hukum dan sesuai moral maupun etika.
Setyawan (2018) Untuk bersaing secara kompetitif dalam era globalisasi ini maka psh membutuhkan karyawan yang cakap dan berkualitas yang dapat memberi dukungan bagi perusahaan untuk mencapai tujuan perusahaan, Serta memiliki sikap mental yang baik, mempunyai semangat kerja yang tinggi sehingga dapat memanfaatkan dan mengendalikan sumber daya lainnya

\section{Indikator-indikator kinerja}

Adapun indikator dari kinerja karyawan menurut Mangkunegara (2011) adalah sebagai berikut : 1 . Kualitas kerja adalah seberapa baik seorang karyawan mengerjakan apa yang seharusnya dikerjakan. 2. Kuantitas kerja adalah seberapa lama seorang pegawai bekerja dalam satu harinya. Kuantitas ini dapat dilihat dari kecepatan kerja setiap pegawai itu masing-masing. 3. Pelaksanaan tugas adalah seberapa jauh karyawan mampu melakukan pekerjaannya dengan akurat atau tidak ada kesalahan. 4. Tanggung jawab terhadap pekerjaan adalah kesadaran akan kewajiban karyawan untuk melaksanakan pekerjaan yang diberikan perusahaan.

Indikator kinerja menurut Wibowo (2014) dalam bukunya Manajemen Kinerja edisi ke 4 menyebutkan bahwa indikator kinerja atau performance indicators dipergunakan secara bergantian dengan ukuran kinerja ( perfomance mesures ), tetapi banyak pula yang membedakannya. Pengukuran kinerja dengan hasil yang dapat dikuntitatifkan dan mengusahakan data setelah kejadian.

Kinerja ditentukan oleh tujuan yang hendak dicapai, dan untuk melakukannya diperlukan adanya motif, tanpa adanya dorongan motif untuk mencapai tujuan, kinerja tidak akan berjalan, dengan demikian tujuan dan motif menjadi indikator utama kinerja. 


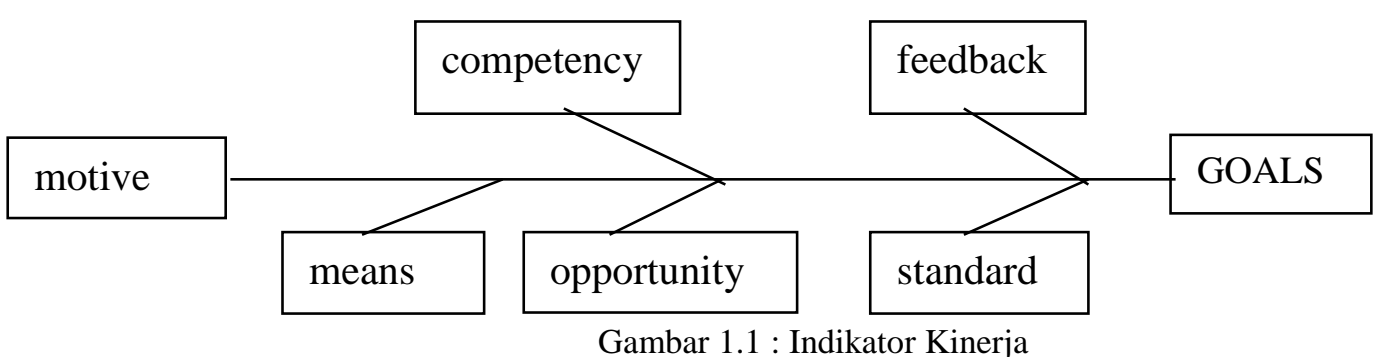

Sumber: Paul Hersey, Kenneth H Blanchard, dan Dewey E Johnson, Management of Organozation Behavior, 1996

\section{Faktor yang mempengaruhi kinerja}

Faktor-faktor yang mempengaruhi kinerja karyawan menurut Sutrisno (2016) yaitu: 1. Efektivitas dan Efisiensi Dalam hubungannya dengan kinerja organisasi, maka ukuran baik buruknya kinerja diukur oleh efektivitas dan efisiensi. Masalahnya adalah bagaimana proses terjadinya efisiensi dan efektivitas organisasi. Dikatakan efektif bila mencapai tujuan, dikatakan efisien bila hal itu memuaskan sebagai pendorong mencapai tujuan. 2. Otoritas dan Tanggung Jawab Dalam organisasi yang baik, wewenang dan tanggung jawab telah didelegasikan dengan baik, tanpa adanya tumpang tindih tugas. Masing-masing karyawan yang ada dalam organisasi mengetahui apa yang menjadi haknya dan tanggung jawabnya dalam rangka mencapai tujuan organisasi. 3. Disiplin Disiplin menunjukkan suatu kondisi atau sikap hormat yang ada pada diri karyawan terhadap peraturan dan ketetapan perusahaan. Masalah disiplin karyawan yang ada di dalam organisasi baik atasan maupun bawahan akan memberikan corak terhadap kinerja organisasi. 4. Inisiatif Inisiatif seseorang berkaitan dengan daya pikir, kreativitas dalam bentuk ide untuk merencanakan sesuatu yang berkaitan dengan tujuan organisasi. Dengan kata lain, inisiatif karyawan yang ada dalam organisasi merupakan daya dorong kemajuan yang akhirnya akan mempengaruhi kinerja

Selain itu ada juga pendapat dari ahli lainya antara lain Hersey, Blanchard, dan Johonson, yang merumuskan adanya tujuh factor kinerja yang mempengaruhi kinerja dan dirumuskan dengan akronim
ACHIEVE, yang memiliki arti sebagai berikut : A - Ability Yaitu Pengetahuan dan Ketrampilan, C - Clarity yaitu pemahaman dan persepsi peran, $\mathrm{H}$ HelpYaitu dukungan organisasi, I Incentive Motivasi dan Kerelaan, E Evaluation (Pembinaan dan umpan balik kinerja),V - Validity Praktik personal yang Valid dan sah ) E - Enviroment Kesesuaian Lingkungan

\section{METODE PENELITIAN}

Penulis dalam melakukan penelitian menggunakan metodologi riset kuantitatif, dimana penulis mencari sumber data di tempat penelitian dengan mengunakan data dari angket dan mengungkap masalah dalam bentuk skor angka data kuantitatif yang selanjutnya diolah dan diuji dengan tehnik analisis statistika.

Jenis data berdasarkan sumbernya terbagi menjadi dua yaitu data primer dan sekunder, Menurut Sugiyono (2016) Sumber primer adalah data yang langsung memberikan data kepada pengumpul data. Penulis menggunakan sumber data primer, dimana data langsung diperoleh dari sumber aslinya, yaitu di Bloom Restaurant Hotel Ayaartta Malioboro Yogyakarta, khususnya waiter dan waitress yang melaksanakan SOP setiap harinya. Penulis dalam mengumpulkan data juga menggunakan data sekunder, Sugiyono (2016) mengatakan bahwa data sekunder merupakan sumber data yang tidak langsung memberikan data kepada pengumpul data, misalnya melalui orang 
lain atau lewat dokumen,Sumber informasi dari penelitian ini menggunakan media seperti internet, selain itu juga data-data pendukung yang didapatkan dari perusahaan yang berhubungan dengan SOP.

Populasi dalam penelitian merupakan wilayah yang ingin diteliti oleh peneliti, Seperti menurut Sugiyono (2016) "Populasi adalah wilayah generalisasi yang terdiri atas : obyek atau subyek yang mempunyai kualitas dan karakteristik tertentu yang ditetapkan oleh peneliti untuk dipelajari dan kemudian ditarik kesimpulannya". Pendapat diatas menjadi acuan bagi penulis untuk menentukan populasi. Populasi karyawan dalam hal ini waiter/ss yang menjadi sumber penelitian berjumlah 14 orang, disesuaikan dengan keadaan sebenarnya yang ada dilapangan.

Metode pengumpulan data yang digunakan dalam penelitian ini yaitu angket/Kuesioner yaitu formulir yang berisikan pertanyaan pertanyaan yang terstruktur dengan bentuk pertanyaan pilihan berganda atau Multiple Choice dan pertanyaan terbuka (Open Question), diajukan kepada seseorang atau sekumpulan orang dalam Hal ini Waiter/waitress Bloom Restoran Ayaartha Hotel. Kemudian Observasi, Metode observasi atau pengamatan memiliki arti sempit yaitu pengamatan menggunakan indera penglihatan dengan cara melihat langsung di Bloom Restaurant Ayaartha Hotel dan mengumpulkan data yang diperlukan sebagai bahan penelitian.

\section{HASIL DAN PEMBAHASAN}

Hotel Ayaartta Malioboro Yogyakarta dibangu $\mathrm{n}$ oleh pemilik baru Ibu Nita dan Bapak Harris pada tahun 2017 dengn model belanda, terletak $2 \mathrm{~km}$ dari jalan Malioboro dan memiliki 71 kamar dengan jenis kamar Superior, Deluxe, Deluxe Balcony, Family Room, Junior Suite dan Premiere Suite. Hotel Ayaartta Malioboro juga dilengkapi fasilitas Hypnotize Coffee Shop \& Bar, In
Bloom Restaurant, Spa dan Massage serta Tropical Swimming Pool.

Penulis dalam melakukan penelitian menggunakan metodologi riset kuantitatif, dimana penulis mencari sumber data di tempat penelitian dengan mengunakan data dari angket dan mengungkap masalah dalam bentuk skor angka data kuantitatif yang selanjutnya diolah dan diuji dengan tehnik analisis statistika.

Penulis menggunakan sumber data primer, dimana data langsung diperoleh dari sumber aslinya, yaitu di In Bloom Restaurant Hotel Ayaartta Malioboro Yogyakarta, khususnya waiter dan waitress yang melaksanakan SOP setiap harinya.

Penulis dalam mengumpulkan data juga menggunakan data sekunder, dimana penulis mencari sumber informasi menggunakan media seperti internet, buku-buku yang berhubungan dengan SOP dan kinerja, selain itu juga data-data pendukung yang didapatkan dari perusahaan yang berhubungan dengan SOP.

\section{Alat Analisis atau Uji Hipotesa}

Penelitian ini menggunakan metode sebagai berikut:

1 Regresi Linier Sederhana

Menurut Syofian Siregar

(2014), dalam bukunya Statistik Parametrik untuk penelitian Kuantitatif,adalah salah satu alat yang dapat digunakan dalam memprediksi permintaan dimasa yang akan datang dengan berdasarkan data masa lalu, atau untuk mengetahui pengaruh satu variabel bebas ( Independen ) terhadap satu variabel tak bebas (dependent) adalah menggunakan regresi linier.

Rumus Regresi Linier Sederhana

$\mathrm{Y}=\mathrm{a}+\mathrm{b} \cdot \mathrm{X}$

Keterangan:

$\mathrm{Y}=$ Variabel terikat ( Dependen )

$=$ Kinerja

$\mathrm{X}=$ Variabel bebas ( Independen ) 
$=\mathrm{SOP}$

$\mathrm{a}$ dan $\mathrm{b}=$ konstanta

Mencari nilai konstanta $\mathrm{b}=\underline{\mathrm{n}} \cdot \sum \mathrm{XY}$ $\sum X . \sum Y$

$$
\text { n. } \sum X^{2}-(
$$

$\left.\sum \mathrm{X}\right)^{2}$

Mencari nilai konstanta $\mathrm{a}=\sum \mathrm{Y}-$ b. $\sum X$

n

Keterangan:

$\mathrm{n}=$ Jumlah data

2. Uji t

Uji $t$ dikenal dengan uji parsial, yaitu untuk menguji bagaimana pengaruh masing-masing variabel bebasnya secara sendiri-sendiri terhadap variabel terikatnya. Uji ini dapat dilakukan dengan mambandingkan $t$ hitung dengan $t$ tabel atau dengan melihat kolom signifikansi pada masing-masing $t$ hitung, proses uji $\mathrm{t}$ identik dengan Uji $\mathrm{F}$ (lihat perhitungan SPSS pada Coefficient Regression Full Model/Enter). Atau bisa diganti dengan Uji metode Stepwise.

$$
\begin{aligned}
& \text { Rumus } \mathrm{t}= \\
& \mathrm{t} \text { hitung }=\frac{\mathrm{r} \sqrt{\mathrm{n}-2}}{\sqrt{1-}}(\mathrm{r})^{2} \\
& \mathrm{t} \text { tabel }=\mathrm{t}(\alpha / 2)(\mathrm{n}-2)
\end{aligned}
$$

Kaidah Pengujian :

Jika, $-\mathrm{t}$ tabel $\leq \mathrm{t}$ hitung $\leq \mathrm{t}$ tabel, maka Ho diterima

Jika, $\mathrm{t}$ hitung > t tabel, maka Ho ditolak

Hasil penelitian lapangan serta diuji dengan metode regresi sederhana kemudian dibuktikan pula menggunakan perhitngan SPSS maka dapat deiketahui bahwa: Berdasarkan penelitian terdapat pengaruh antara SOP dengan kinerja, dibuktikan dengan $\mathrm{R}$ hitung 0,685 yang lebih besar dari $\mathrm{R}$ tabel yaitu 0,576. B) terdapat hubungan posistif antara SOP dengan kinerja dimana $\mathrm{F}$ hitung 10,69 lebih besar dari $F$ tabel 4,60, dengan df sebesar 3,245 lebih besar dari standar error 2,459 karena standar deviasi kinerja lebih besar dari standar error maka model regresi sederhana bagus bertindak sebagai prediktor kinerja.

Rata-rata tingkat kinerja 33,29 dengan standar deviasi sebesar 3,245, yang artinya, tingkat kinerja berkisar 33,29 $\pm 3,245$ dan Kontribusi yang disumbangkan SOP (X) $47 \%$ terhadap kinerja $(\mathrm{Y})=53 \%$, dari data tersebut, SOP hanya memberikan pengaruh terhadap kebaikan kinerja sebesar $47 \%$ maka dapat disimpulkan bahwa, pelaksanaan SOP masih berjalan tetapi kurang baik, sehingga pengaruh terhadap kinerja tidak maksimal kearah positif, bila hal ini masih terus bertahan maka yang akan dirugikan adalah: perusahaan, owner, tamu dan pelanggan, karyawan Yang akibatnya peusahaan tidak dapat bersaing menghadapi perkembangan jaman maupun tidak mampu bertahan terhadap kepungan kompetitor lama maupun baru.

Berdasarkan nilai $\mathrm{F}$ hitung dari tabel anova sebesar $=10,630$ dan nilai $\mathrm{F}$ tabel $=4,60$. Berdasarkan data diatas maka $\mathrm{F}$ hitung $10,630>$ dari $\mathrm{F}$ tabel $=4,60$, berarti Ho ditolak, Ha diterima yang artinya ada pengaruh dan ada hubungan antara SOP dengan kinerja waiter/ss di In Bloom Restaurant Hotel Ayaartta Malioboro Yogyakarta. Berdasarkan data tersebut semua pihak perlu menyadari dengan sungguh-sungguh penting nya pelaksanaan SOP dengan baik, benar dan berkesinambungan agar kinerja waiter/ss berjalan kearah positif. Sehingga tidak adalagi penolakan dan usaha untuk meremehkan pelaksanaan SOP serta akan meletakan SOP pada posisi penting dalam pelaksanaan kerja serta sebagai panduan untuk semua karyawan, tanpa kecuali.

Uji $\mathrm{T}$ hitung $=2,521>\mathrm{t}$ tabel $=$ 2,145. Karena $\mathrm{t}$ hitung lebih besar dari $\mathrm{t}$ tabel maka Ho ditolak, sehingga $\mathrm{Ha}$ diterima, sehingga terdapat pengaruh yang signifikan antara SOP dengan kinerja. . 


\section{KESIMPULAN}

Berdasarkan hasil penelitian dapat disimpulkan bahwa terdapat pengaruh positif antara SOP dengan kinerja, pelaksanaan SOP masih berjalan tetapi kurang baik, sehingga pengaruh terhadap kinerja tidak maksimal kearah positif, Hasil penelitian ini membuktikan bahwa SOP memiliki pengaruh terhadap kinerja Waiter/ss di in bloom Restoran Hotel Ayaartta Malioboro Yogyakarta

Pimpinan selalu melaksanakan sosialisasi tentang SOP kepada semua staff yang ada, baik pemanen, konrak, harian dan lainnya, level atas sampai basic, karyawan baru maupun lama, agar didapat persamaan langkah menuju standar perusahaan yang baik.

Selalu mengadakan training atau penyegaran secara berkala dan terus menerus, agar jangan sampai terjadi kelupaan atau ada yang belum mendapatkan SOP dengan baik ( karyawan baru), serta meyakinkan bahwa SOP benar-benar sudah dipahami oleh setiap karyawan.

\section{DAFTAR PUSTAKA}

Atmoko, Tjipto. (2013). Standard Operasional Prosedur (SOP) Dan Akuntabilitas Kinerja Instansi Pemerintah

ED, Durachim., dan Faizal, H. (2017). Restoran Bisnis Berbasis Standar Kompetensi. Jurnal Pariwisata, IV(1), 10-21. Retrieved from http://ejournal.bsi.ac.id/ejurnal/index. php/jp/article/download/1701/1340

Guritno, Bambang dan Waridin. (2005).Pengaruh Persepsi Karyawan Mengenai Perilaku Kepemimpinan,Kepuasan Kerja dan Motivasi Terhadap Kinerja.JRBI.Vol 1.No 1

Hersey, Paul and Blanchard, Kenneth $\mathrm{H}$. and Johnson, Dewey E. (1996). Management Of Organizational
Behavior, 7th Edition.New Jersey:

Prentice Hall,Inc

Jones, Gareth R. (2001). Organizational

Theory Text and Cases. Third

Edition. New Jerse,. America:

Prentice Hall International, Inc

Mangkunegara. (2011). Manajemen

Sumber Daya Perusahaan. PT .

Remaja Rosdakarya. Bandung.

Marsum W. A., dan Siti Fauziah. 2016.

Professional Waiter. Yogyakarta.

Andi

Budiharjo, M. ( 2014 ). Panduan Praktis Menyusun SOP. Jakarta : Raih Asa

Sukses

Purnamasari. (2015) Panduan menyusun SOP Standard Operating Procedure, Jakarta:Kobis ( Komunitas Bisnis)

Prihandini, Niken dan Mayasari, Citra Unik. (2019) Penerapan minimum charge untuk outside guest restoran di Amanjiwo Resort, Journal of Tourism and Economic Vol.2 No. 1 2019 Page 1-9

Soemohadiwidjojo, Arini, T. (2014). Mudah Menyusun SOP (Standard Operating Procedure), Jakarta: Penebar Plus

Setyawan, Erwin Budi. (2018). Pengaruh Motivasi dan Disiplin terhadap kinerja karyawan (Studi Kasus Pada CV. Indobatu Makmur Palembang), Journal of Tourism and Economic Vol.1 No.2, 2018 page 101-108

Sugiyono. (2016). Metode Penelitian Kuantitatif, kualitatif dan R\&D, Bandung : Alfabeta

Sujatno, A. B. (2011). Hospitality: Secret Skill, Attitude and Performance for Restaurant Manager. Edisi Pertama. Yogyakarta: Penerbit ANDI.

Sulistiyani. (2003). Manajemen Sumber Daya Manusia.Graha Ilmu.Yogyakarta

Sutrisno, Edy. (2011). Manajemen Sumber Daya Manusia Penerbit : Jakarta Kencana

Siregar, Syofian. (2014). Statistik Parametrik untuk Penelitian Kuantitatif, Jakarta : Bumi Aksara 
Syailendra, Annie. (2015). Langkahlangkah Praktis membuat SOP (Standard Operating Procedures), Trans Idea Publishing
Wibowo. ( 2014 ). Manajemen Kinerja. Edisi keempat Jakarta: Rajawali Pers Yuniarsih,Tjutju dan Suwatno. (2011). Manajemen Sumber Daya Manusia Bandung : alfabeta 